Journal of Animal and Feed Sciences, 1, 1992, 289-294

\title{
A note on blood cholesterol as an indicator of body fatness in ducks
}

\author{
J. Książkiewicz ${ }^{1}$, Helena Kontecka ${ }^{2}$ and L. Nogowski ${ }^{3}$ \\ 'Department of Waterfowl Breeding, Poultry Research Centre, Poznań-Zakrzewo, \\ 62-022 Swiqtniki $n /$ Warta, Poland \\ ${ }^{2}$ Department of Poultry Breeding and Husbandry, Agricultural University of Poznan and \\ ${ }^{3}$ Department of Animal Physiology and Biochemistry, Agricultural University of Poznań, \\ Wolyńska 33, 60-637 Poznań, Poland
}

(Received 27 November 1992; accepted 23 February 1993)

KEY WORDS: duck, cholesterol, body fatness

INTRODUCTION

In birds cholesterol is needed as a structural component of cell membranes and as a precursor of sex and adrenal hormones, vitamin $\mathrm{D}$ and bile acids (Hargis, 1988). Most studies on cholesterol have focused on the influence of genetic and nutritional factors on its concentration in egg yolk as well as on the harmful effects of cholesterol on human health (Griffin, 1992). Only a few studies have attempted to determine the relationship between blood cholesterol level and such traits as body weight of 16 week-old turkeys (Smith and Savage, 1991) or weight of fatty liver in geese (Karasiński, 1973; Niespodziewański, 1971). Studies on the correlation between physiological or biochemical indices and production traits in ducks have not been undertaken to date. The search for those blood indices which can be correlated with desired traits and aid in the selection of live birds is a current research problem.

The objective of the study reported here was to determine the relationship between the plasma cholesterol level (total, free and esterified) and the weight and composition of dressed carcasses of 7 week-old ducks and drakes.

\section{MATERIAL AND METHODS}

The study was carried out on 30 drakes and 31 ducks from a male Pekin-type breeding line. The birds were kept in a closed house with regulated environmental conditions until 3 weeks of age, after which they were transferred to open, 
partially roofed, straw-lined bird yards. The birds were fed to appetite on a balanced feed mixture. In the first 3 weeks the diet was composed of (in \%): maize 30 , wheat 28 , barley 14 , soya bean oil meal 11 , meat-and-bone meal 7 , fish meal 5 , fodder yeasts 2 , dicalcium phosphate 2, vitamin-mineral premix 1 and contained $22.6 \%$ crude protein $(\mathrm{CP})$ and $3000 \mathrm{kcal} \mathrm{ME} / \mathrm{kg}$. In the last 4 weeks the diet was composed of (in \%): wheat 55 , barley 10 , soya bean oil meal 16 , meat-and-bone meal 8 , dried grass, fat concentrate and limestone 3 each, dicalcium phosphate and vitamin-mineral premix 1 each, and contained $17.4 \%$ $\mathrm{CP}$ and $2700 \mathrm{kcal} \mathrm{ME} / \mathrm{kg}$.

Blood was sampled from a wing vein following $24 \mathrm{~h}$ fasting and $16 \mathrm{~h}$ before planned slaughter. EDTA (ethylene-diaminetetraacetate - Sigma) was used as an anticoagulant. After centrifugation the plasma was stored at $-20^{\circ} \mathrm{C}$ until analysis. Total cholesterol and free cholesterol were assayed enzymatically using cholesterol oxidase and esterase (Sigma) according to Richmond (1973). The level of esterified cholesterol was expressed as the difference between total and free cholesterol levels.

At 7 weeks of age the ducks were killed and plucked. Evisceration, separation of intestinal and abdominal fat and dissection analysis according to the method of Ziolecki and Doruchowski (1989) were carried out after 18 hours of cooling at $4{ }^{\circ} \mathrm{C}$. The skin and subcutaneous fat were removed from the dressed carcass and weighed, then the breast, thigh and lower-thigh muscles were separated and weighted.

The data were subjected to analysis of variance and the correlation coefficients (r) between the analyzed traits were calculated.

\section{RESULTS}

The total, free and esterified cholesterol levels in the plasma of drakes were higher than in ducks (Table 1). The difference between the sexes was statistically significant for the total and esterified cholesterol only due to high variability, which was higher in females than in males.

TABLE 1

Cholesterol and cholesterol fraction levels $(\mathrm{mmol} / \mathrm{l})$ in the blood of 7 week-old drakes and ducks

\begin{tabular}{lcc}
\hline \multicolumn{1}{c}{ Analyte } & $\begin{array}{c}\text { Drakes } \\
(\mathrm{n}=30)\end{array}$ & $\begin{array}{c}\text { Ducks } \\
(\mathrm{n}=31)\end{array}$ \\
\hline Total cholesterol $(\mathrm{TCH})$ & $1.425^{\mathrm{a}} \pm 0.202$ & $1.287^{\mathrm{b}} \pm 0.281$ \\
Free cholesterol $(\mathrm{FCH})$ & $0.717^{\mathrm{a}} \pm 0.177$ & $0.688^{\mathrm{a}} \pm 0.210$ \\
Esterified cholesterol $(\mathrm{ECH})$ & $0.707^{\mathrm{a}} \pm 0.132$ & $0.597^{\mathrm{b}} \pm 0.158$ \\
\hline
\end{tabular}

Mean values in rows indexed with different letters differ significantly at $P \leqslant 0.05$ 
TABLE 2

Body weight, dressing percentage and composition of carcasses with necks of 7 week-old drakes and ducks

\begin{tabular}{|c|c|c|c|c|c|c|c|c|c|c|}
\hline & \multirow[b]{2}{*}{ Sex } & \multirow[b]{2}{*}{$\begin{array}{c}\text { Live } \\
\text { body } \\
\text { weight, } \\
\text { g } \\
\text { LBW }\end{array}$} & \multirow[b]{2}{*}{$\begin{array}{l}\text { Weight of } \\
\text { eviscera- } \\
\text { ted carcass } \\
\text { with neck, g } \\
\text { WEC }\end{array}$} & \multirow[b]{2}{*}{$\begin{array}{c}\text { Dressing } \\
\text { percen- } \\
\text { tage } \\
\text { DP }\end{array}$} & \multirow[b]{2}{*}{$\begin{array}{l}\text { Intes- } \\
\text { tinal } \\
\text { fat, } \\
\% \text { LBW } \\
\text { IF }\end{array}$} & \multicolumn{5}{|c|}{ Content in carcass with neck, $\%$} \\
\hline & & & & & & $\begin{array}{c}\text { Breast } \\
\text { muscles } \\
\text { BM }\end{array}$ & $\begin{array}{c}\text { Thigh and } \\
\text { lower-thigh } \\
\text { muscles } \\
\text { TLTM }\end{array}$ & $\begin{array}{c}\text { Total } \\
\text { muscles } \\
\text { TM }\end{array}$ & $\begin{array}{c}\text { Skin with } \\
\text { subcuta- } \\
\text { neous fat } \\
\text { SSF }\end{array}$ & $\begin{array}{c}\text { Abdominal } \\
\text { fat } \\
\text { AF }\end{array}$ \\
\hline \multirow[t]{2}{*}{$\overline{\text { Drakes }}$} & $\overline{\mathrm{x}}$ & $2826^{a}$ & $1817^{a}$ & $64.3^{\mathrm{a}}$ & 0.7 & $12.0^{\mathrm{a}}$ & $15.0^{\mathrm{a}}$ & 27.0 & $27.7^{\mathrm{a}}$ & $1.7^{\mathrm{a}}$ \\
\hline & $\mathrm{S}_{\mathrm{D}}$ & 74.6 & 53.6 & 1.3 & 0.2 & 1.5 & 0.8 & 1.2 & 1.6 & 0.4 \\
\hline \multirow[t]{2}{*}{ Ducks } & $\overline{\mathrm{x}}$ & $2684^{b}$ & $1763^{\mathrm{b}}$ & $65.7^{\mathrm{b}}$ & 0.8 & $13.0^{\mathrm{b}}$ & $14.1^{\mathrm{b}}$ & 27.1 & $28.9 \mathrm{~b}$ & $1.9^{\mathrm{b}}$ \\
\hline & $\mathrm{S}_{\mathrm{D}}$ & 51.0 & 53.6 & 1.6 & 0.2 & 1.3 & 0.8 & 1.2 & 2.0 & 0.4 \\
\hline
\end{tabular}

$\mathrm{a}, \mathrm{b}-$ mean values in columns indexed with different letters differ significantly at $\mathrm{P} \leqslant 0.05$

TABLE 3

Coefficients of correlation ( $\mathrm{r}$ ) between the content of cholesterol (mmol/1) in blood and the content of some components (\%) in the carcasses of 7 week-old drakes and ducks (abbreviations as in Tables 1 and 2)

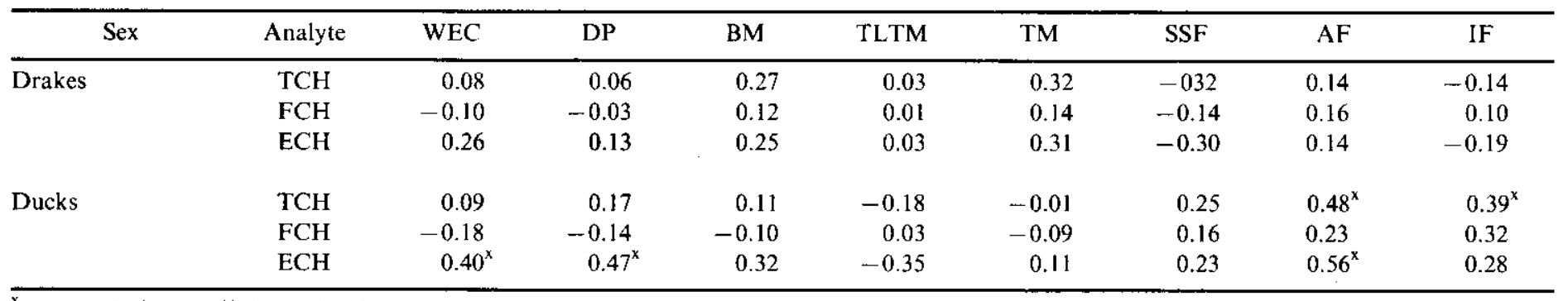


The results presented in Table 2 show that the drake carcasses with necks were on average $54 \mathrm{~g}$ heavier than duck carcasses and this difference was statistically significant. The ducks carcasses contained a significantly larger proportion of skin plus subcutaneous fat, abdominal fat and breast muscles but less thigh and lower-thigh muscles than the drakes. The birds did not differ by sex in respect to the total breast and leg muscle contents or in the proportion of intestinal fat in the carcass.

No statistically significant correlations between total, free and esterified plasma cholesterol levels and the studied composition of dressed drake carcasses (Table 3) were found. In ducks, however, the level of total blood cholesterol was positively correlated with the abdominal fat $(r=0.48)$ and intestinal fat $(r=0.39)$ content in the carcass. Statistically significant correlations were found in females between the blood level of esterified cholesterol and weight of the dressed carcass $(r=0.40)$, dressing percentage $(r=0.47)$ and the percentage of abdominal fat in the carcass $(r=0.56)$.

\section{DISCUSSION}

Comparison of the body composition of the studied 7 week-old ducks with ducks evaluated in an international test shows that the ducks used in the study reported here were not inferior in terms of breast and leg muscle content to birds of similar body weight and of the same age coming from Hungary, Germany, Russia and Czechoslovakia (Otsenka, 1989). A similar skin and subcutaneous fat content of $28.6 \%$ was reported in ducks and drakes of the same age and line by Lewczuk et al. (1984). A confirmation of our finding that 7 week-old ducks had a greater fat content than drakes can be found in the results of the study by Lewczuk et al. (1978) in which the percentage of skin and subcutaneous fat equalling 32.2 in ducks and $29.4 \%$ in drakes, respectively, were reported. Sex differences in favour of females were also found in this study in respect to abdominal and intestinal fat, which totalled 29.5 and $41.7 \mathrm{~g}$, respectively.

The mean total blood cholesterol level in the studied birds did not differ from the values found by Ducci et al. (1992) in 13-week-old Muscovy ducks and, after recalculation, equalled $55 \mathrm{mg} \%$ in drakes and $50 \mathrm{mg} \%$ in ducks. These authors found that the total blood cholesterol level changed with age from weeks 6 to 25 of life (determinations were made every 3 weeks) with peak values being found in weeks 6 (from 97 to $185 \mathrm{mg} \%$ ) and 16 (from 95 to $113 \mathrm{mg} \%$ ). The small sample size in the cited study makes comparison of differences between sexes difficult.

Many studies have been carried out in Poland on plasma cholesterol level in geese. These values ranged from 150 to $490 \mathrm{mg} \%$ and changed depending on age and feeding regimen - to appetite, limited or force feeding (Karasiński, 1973; Niespodziewański, 1971; Uhaczowa et al., 1969; Woszczyk et al., 1981). 
The correlation coefficients determined in this study between the total blood cholesterol level and percentage of abdominal and intestinal fat in ducks were similar to the values found between other fatty compounds in the blood and the fat deposition of broiler chicks by Griffin et al. (1982), Swierczewska et al. (1990) and Whitehead and Griffin (1982). Griffin et al. (1982) found a correlation coefficient, ranging from 0.33 in females to 0.50 in males between the blood triglyceride content and the fat content in the carcasses of 8 week-old broiler chicks. Statistically significant correlation between blood triglyceride contents of 7 week-old chicks and abdominal fat content were found in males $(r=0.386)$ and females $(r=0.359)$ by Świerczewska et al. (1990). Correlation between sum of triglyceride bound with very low density lipoprotein and low density lipoprotein and the fat content in the carcass of 7 week-old chicks ranging from 0.43 to 0.60 were found by Whitehead and Griffin (1982).

No relationship was found in drakes between blood cholesterol level and body fat deposition in spite of reports in literature showing a dependence between blood lipids and body fatness of broiler cockerels. The reason for this may be the lower fat content of drake carcasses than of ducks.

\section{CONCLUSIONS}

In female ducks statistically significant correlation was found between the total plasma cholesterol level and the percentage of abdominal $(r=0.48)$ and intestinal fat $(\mathrm{r}=0.39)$. It seems that total plasma cholesterol evaluation may be useful for selection in breeding for decreased body fat content.

\section{REFERENCES}

Ducci M., Sighieri C., Gazzano A., Paci G., Frateschi T. L., Martelli F., 1992. Physiological blood analytes in growing Muscovy duck. In: Proceedings of 9th International Symposium on Waterfowl, Pisa, pp. 49-51

Griffin H. D., 1992. Manipulation of egg yolk cholesterol: a physiologist's view. World Poultry Sci. J. $48,101-112$

Griffin H. D., Whitehead C. C., Broadbent L. A., 1982. The relationship between plasma triglyceride concentrations and body fat content in male and female broilers - a basis for selection? $\mathrm{Br}$. Poultry Sci. 23, 15-23

Hargis P. S., 1988. Modifying egg yolk cholesterol in the domestic fowl-a rcview. World Poultry Sci. J. $44,17-29$

Karasiński D., 1973. Morfologia i ciężar właściwy krwi oraz poziom cholesterolu w surowicy u przymusowo tuczonych gesi. Rocz. AR Pozn. 66, 91-96

Lewczuk A., Bochno R., Michalik D., 1978. Przydatność wagi ciała i niektórych cech poubojowych do oceny zawartości mięsa, kości i tłuszçu w tuszkach kaczych. Zesz. nauk. ART Olszt. 16, $177-187$

Lewczuk A., Bochno R., Janiszewska M., Michalik D., 1984. Skład tkankowy tuszek kaczek rodu A-44 w zależności od wieku i płci ptaków. Zesz. nauk. ART Olszt. 27, 149-159

Niespodziewański M., 1971. Poziom cholesterolu, jego frakcji, bialka ogólnego w surowicy, glukozy we krwi oraz wartość hematokrytowa u gęsi tuczonych na stłuszczone wątroby. Rocz. Nauk. rol. Ser. B. $93,265-280$ 
Otsenka 20-vo mezhdunarodnogo ispitania po otkormu utok, 1989. Miedzinárodná kontrolno-skúšobná stanica hydiny, Ivanka pri Dunaji

Richmond W. 1973. Preparation and properties of a cholesterol oxidase from Nocardia sp. and its application to the enzymatic assay of total cholesterol in serum. Clin. Chem. 19, 1350-1356

Smith E.J., Savage T.F., 1991. Genetic variation in total plasma and high density lipoprotein cholesterol and body weight in medium White turkeys. Poultry Sci. 71, 807-812

Świerczewska E., Krasicka B., Riedel J., Grzybowska A., 1990. The triglyceride content of blood plasma as an indicator of fat depositon in chicken. Ann. Warsaw Agric. Univ. SGGW-AR, Anim. Sci. 25, 33-36

Uhaczowa Z., Szostak D., Lebioda B., Sczaniecka E., 1969. Zmiany w składzie chemicznym surowicy krwi podczas tuczu gęsi na stluszczone wątroby. Post. Drob. 11, 111-117

Whitehead C.C., Griffin H.D., 1982. Plasma lipoprotein concentration as an indicator of fatness in broilers: Effect of age and diet. Br. Poultry Sci., 23, 299-305

Woszczyk J., Karasiński D., Bieliński K., 1981. Wpływ intensywności żywienia na niektóre wykładniki gospodarki lipoproteidowej w krwi brojlerów gęsich. Rocz. Nauk. Zoot. 8, 35-40

Ziołecki J., Doruchowski W., 1989. Metoda oceny wartości rzeźnej drobiu. Ed. by COBRD, Poznań

\section{STRESZCZENIE}

\section{Cholesterol we krwi jako wskaźnik otłuszczenia kaczek}

U 61 kaczek mięsnych obu płci określono w 7 tygodniu życia zależności między zawartością cholesterolu ogólnego, wolnego i zestryfikowanego w osoczu krwi a otłuszczeniem tuszy.

Statystycznie istotne wartości współczynników korelacji stwierdzono jedynie u samic między zawartością cholesterolu ogólnego a zawartością tluszczu sadełkowego $(r=0,48)$ i okołojelitowego $(\mathrm{r}=0,39)$, a także między zawartością cholesterolu zestryfikowanego a masą tuszki patroszonej $(r=0,40)$, wydajnością rzeźną $(r=0,47)$ oraz zawartością thuszczu sadełkowego w tuszce $(r=0,56)$. 